\title{
Nutritional, phytoconstituents, and free radical scavenging potentials of Cola lepidota K. Schum. and Irvingia gabonensis (Aubry-Lecomte ex O’Rorke) Baill. leaves
}

\section{Agada Adaeze Bob-Chile ${ }^{\mathbf{1}}$ and Peter Uchenna Amadi ${ }^{2}$}

\author{
${ }^{1}$ Imo State University. Department of Biochemistry. Owerri. Nigeria. \\ ${ }^{2}$ University of Port Harcourt. Department of Biochemistry. Choba Rivers State. \\ Nigeria. Email: amadi@imsu.edu.ng.
}

\begin{abstract}
This study was carried out to determine the essential oil components, protein qualities, fatty acid composition, and free radical scavenging potentials of leaves of Cola lepidota K. Schum. (Malvaceae) and Irvingia gabonensis (Aubry-Lecomte ex O’Rorke) Baill. (Irvingiaceae) using chromatographic and spectrophotometric methods. Thirty five bioactive components were isolated from C. lepidota leaves with myrcene, phytol, ephedrine, hexadecanoic acid, and 1,14-tetradecanediol as the main compounds while phytol, 2-furancarboxaldehyde, 5-(hydroxymethyl)-, 1-hexadecyne, carotene, and humulene were the predominant components of the I. gabonensis leaves. Leucine and arginine were the predominant essential amino acids, whereas glutamic acid and serine were the main nonessential amino acids in both leaves. The total amino acid (TAA) $(70.92 \mathrm{~g} / 100 \mathrm{~g})$, total non-essential amino acid (TNEAA) (45.87 $\mathrm{g} / 100 \mathrm{~g})$, and total acidic amino acid (TAAA) $(23.01 \mathrm{~g} / 100 \mathrm{~g})$ of C. lepidota were high whereas I. gabonensis recorded higher Total essential amino acid (TEAA) $(28.98 \mathrm{~g} / 100 \mathrm{~g})$, total aromatic amino acid (TArAA) (7.21 g/100 g), total branched chain amino acid (TBCAA) (14.28 g/100g), predicted protein efficiency ratios (P-PERs), and essential amino acid index (EAAI). C. lepidota contained $55.72 \%$ of unsaturated fatty acids, with predominance of linolenic and linoleic acids, while I. gabonensis produced $74.46 \%$ of saturated fatty acids, having myristic, lauric, and palmitic acid as the main compounds. All the radical scavenging potentials of both leaves were concentration dependent and produced higher DPPH, hydrogen peroxide, and ABTS radical scavenging potentials than the standards. This study has thus provided the scientific backing for the inclusion of both leaves for dietary and therapeutic purposes.
\end{abstract}

Keywords: Cola lepidota; Monkey kola; Irvingia gabonensis; Bush mango; Essential oil; Amino acids; Fatty acids; Free radicals.
Received

August 7, 2019

Accepted

March 21, 2020

Available on line on

March 25, 2020

Released

April 30, 2020

Full Text Article

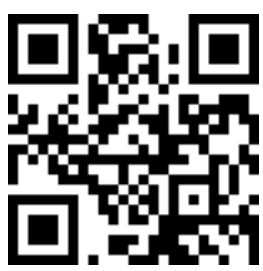

ORCID

D 0000-0002-4565-7685 Agada Adaeze Bob-Chile

D 0000-0001-6265-6724 Peter Uchenna Amadi 


\section{Introduction}

The paucity of information, and non existence of a database for properties of local foods and fruits, are major contributors to the under-exploitation of some of the available medicinal plants in nature (Grivetti and Ogle, 2000).

Evidently, in Nigeria, many local fruits and leaves are underutilized and could face extinction. Erosion of practices encouraging the utilization of local medicinal plants could be drawn to the behavioural or lifestyle changes, massive migration to urban areas, and overdependence on popularly positioned resources (Joshi and Joshi, 2005), therefore accounting for the high rate of diet related diseases and malnutrition. In other words, proposing a return to the investigation of local plants holds the key to the adequate provision of nutrients, and other bioactive components for the populace.

Of such underexploited plants, are the leaves of Cola lepidota K. Schum. (Malvaceae) and Irvingia gabonensis (Aubry-Lecomte ex O’Rorke) Baill. (Irvingiaceae). C. lepidota also known as the monkey kola, is one of the members of the Cola species, and the Family Malvaceae that bear sweet edible fruits. In Nigeria, they are mostly consumed by the southerners and some Eastern part of Nigeria. The fruits of $C$. lepidota have been widely evaluated for its nutritional and biochemical properties (Pamplona-Roger, 2008; Singh et al., 2010). However, the leaves of this plant have been surprisingly overlooked in terms of nutritional and ethnomedicinal applications.

I. gabonensis is known as bush mango by local inhabitants, and belongs to the Family Irvingaceae which are green tall trees with perennial life cycle. The bush mango boasts of rich ethnobotanical profile due to extensive tradomedical applications for several disease conditions (Lowe et al., 2000; Ezeasor et al., 2017). The seeds also called Ogbono or Ugiri seeds in Igbo, is a known soup thickener, and have been shown to posses weight loss and hypoglycaemic effects coupled with other therapeutic potentials (Rosen and Spiegelman, 2000; Ngondi et al., 2009). However, the leaves of this popular culinary plant have seen little utilization regarding its ethnomedicinal potentials.

We understand that the under-exploitation of the leaves of both C. lepidota and I. gabonensis have occurred as a consequence of paucity of information about their nutrient composition. Hence, this study was carried out to determine the essential oil, fatty acid, protein qualities, and in vitro antioxidant potentials of $C$. lepidota and I. gabonensis leaves.

\section{Methods}

\section{Sample collection, identification and preparation}

Freshly harvested leaves of C. lepidota, and I. gabonensis were obtained from farmlands at Mbaise in Imo State Nigeria. The leaves were identified by the botanist at Department of Plant Science and Biotechnology (DPSB), Imo State University Owerri and the voucher specimen deposited in the DPSB herbarium.

After cleaning the samples of debris using distilled water, the leaves were dried under open air, and ground continuously to powder size.

\section{Extraction and analysis}

Using a Clevenger type apparatus, the hydrodistilled extracts of the samples (100 g) were obtained and analyzed in a HP Chem Station Rev. A 09.01 machine, under the following conditions;

Detector; FID, Injection type and ratio; split and 20:1, inlet temp; $150{ }^{\circ} \mathrm{C}$, Column; HP5MS (of dimension $30 \mathrm{~m} \times 0.25 \mathrm{~mm} \times 0.25 \mu \mathrm{m}$, carrier gas; hydrogen, flow rate; $1.0 \mathrm{~mL} / \mathrm{min}$, carrier gas pressure; $22 \mathrm{psi}$, compressed air pressure; $28 \mathrm{psi}$, oven 
parameters; initial temp of $40{ }^{\circ} \mathrm{C}$, run rate at for 2 min at $200{ }^{\circ} \mathrm{C}$, ramping $\left(5^{\circ} \mathrm{C} / \mathrm{min}\right.$ first and $200^{\circ} \mathrm{C} / \mathrm{min}$ final).

\section{Identification of the components of essential oils}

The chromatogram was interpreted using NIST database from the comparison of the spectrum of the unknown components with the spectrum of the known components stored in the NIST library. The name, percentage areas, and percentage concentrations of the components of the test materials were thus ascertained.

\section{Amino acid analysis of the leaves}

The method of Benitez, (1989) was applied for the amino acid content determination of the leaves. Briefly, 100g of the samples were immersed in $500 \mathrm{~mL}$ of mixture of chloroform and methanol $(2: 1)$ and sieved after $48 \mathrm{~h}$. The extracts were concentrated in a rotary evaporator and were transferred the Amino Acid Autoanalyzer (Technicon Sequential Multi-Sample). Tryptophan was measured colorimetrically following the procedure of Rama Rao et al. (1974).

\section{Determination of protein quality parameters}

The groups of amino acids were arithmetically determined following the procedure of Amadi et al. (2017). The estimation of the indicators of protein qualities; Predicted protein efficiency ratios (P-PERs I, II, and III) were carried out using standard equations of Chavan et al. (2001) below:

$$
\begin{aligned}
& \text { I. PER }=-0.684+0.456(\text { Leu })-0.047(\text { Pro }) \\
& \text { II. PER }=-0.468+0.454(\text { Leu })-0.105(\text { Tyr }) \\
& \text { III. PER }=-1.816+0.435 \text { (Met) }+0.780(\text { Leu })+0.211(\text { His })-0.944(\text { Tyr }) .
\end{aligned}
$$

The method of Steinke et al. (1980) as modified, was adopted for the determination of essential amino acid index (EAAI) shown below;

$$
\mathrm{EAAI}=9 \sqrt{\frac{\mathrm{mg} \text { of Lys in } 1 \mathrm{~g} \text { of test protein } \times \text { essential amino acids }+\mathrm{His}}{\mathrm{mg} \text { of Lys in } 1 \mathrm{~g} \text { of Reference protein }}}
$$

\section{Determination of fatty acid methyl esters}

The procedure of Agomuo et al. (2017) was adopted for the extraction of the oils from the leaves using a mixture of n-hexane and isopropyl alcohol in a ration of 3:2. The Fatty acid methyl esters (FAMES) were generated by saponifying the extracted oils in a mixture of $3 \mathrm{~mL} 0.5 \mathrm{M} \mathrm{KOH}$ and $2 \mathrm{~mL}$ methanol and neutralized in $3 \mathrm{~mL}$ of $14 \% \mathrm{BF}_{3}$ in $100 \mathrm{~mL}$ hydrochloric acid. Methylation was completed after heating at $90{ }^{\circ} \mathrm{C}$ for $10 \mathrm{~min}$. Precisely $1 \mu \mathrm{L}$ of the FAMES was drawn out and transferred to the chromatography machine for analysis. The chromatography conditions were as follows:

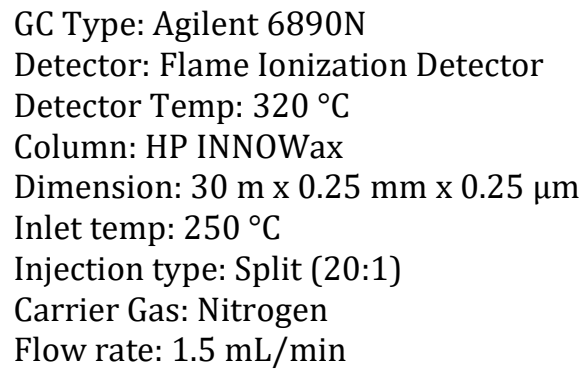


Carrier gas and compressed air pressure: 22psi and 35psi

Oven conditions: Initial temp $\left(60^{\circ} \mathrm{C}\right)$, ramping (first, $12^{\circ} \mathrm{C} / \mathrm{min}$ for $20 \mathrm{~min}$ and second, $15^{\circ} \mathrm{C} / \mathrm{min}$ for $3 \mathrm{~min}$ ). The identification of components and peak areas and percentages were obtained using standard chemstation system after matching with standard methyl esters.

\section{potential \\ Determination of in vitro antioxidant properties: DPPH radical scavenging}

The spectrophotometric method of Shimada et al. (1992) was adopted for the determination of DPPH radical scavenging potentials of the leaves.

The hydrogen peroxide radical \% inhibition of the leaves was estimated following the procedure of Ruch et al. (1989) by spectrophotometry.

Nitric oxide radical scavenging potentials of the leaves were spectrophotometrically determined by the procedures of Alam et al. (2013).

ABTS radical scavenging potentials of the leaves were determined according to the method of Pellegrini et al. (2003) at absorbance of $734 \mathrm{~nm}$ while the method of Sutharsingh et al. (2011) was adopted to determine the ferric reducing antioxidant potentials.

\section{Result and discussion}

Table 1 presents the essential oils isolated from leaves of $C$. lepidota. Till date, no study has characterized the essential oil components of this leaf. Thirty five compounds were quantitiated, with phytol, myrcene, benzenamine, ephedrine, hexadecanoic acid, and 1,14-Tetradecanediol, occurring as the main compounds.

Table 1. Essential oil contents of Cola lepidota.

\begin{tabular}{llc}
\hline S/N & Essential oils & Amount (\%) \\
\hline 1 & Eucalyptol & 1.13 \\
2 & Benzofuran, 2,3-dihydro- & 0.98 \\
3 & trans-2-(1-Pentenyl)furan & 2.21 \\
4 & Camphene & 1.35 \\
5 & Linalool & 0.76 \\
6 & Butanal, ethylhydrazone & 0.58 \\
7 & 2-Acetamido-d-mannitol & 0.83 \\
8 & Hexanethioic acid, S-ethyl ester & 3.29 \\
9 & Dotriacontane & 0.73 \\
10 & Hexatriacontane & 0.79 \\
11 & 3,8-Nonadien-2-one, (E)- & 0.87 \\
12 & Pentalene, octahydro-1-(2-octyldecyl)- & 0.94 \\
13 & Pentadecanoic acid & 0.57 \\
14 & 1,14-Tetradecanediol & 5.12 \\
15 & 3,7,11,15-Tetramethyl-2-hexadecen-1-ol & 1.08 \\
16 & Copaene & 1.70 \\
18 & Hexadecanoic acid & 7.61 \\
19 & 12-Octadecenoic acid & 2.63 \\
20 & Phytol & 10.49 \\
21 & Palmitaldehyde, diallyl acetal & 0.94 \\
22 & Octadecanoic acid, 2-hydroxy-1-(hydroxymethyl)ethyl ester & 0.57 \\
23 & Myrcene & 11.82 \\
\hline
\end{tabular}


Table 1. Continued.

\begin{tabular}{llc}
\hline S/N & Essential oils & Amount (\%) \\
\hline 24 & Germacrene D & 0.75 \\
25 & Squalene & 0.75 \\
26 & 1-Pentene, 5-bromo- & 1.12 \\
27 & 1,5-Heptadiene, 2,3,6-trimethyl- & 3.00 \\
28 & Cardanol & 1.06 \\
29 & 2,6,10-Dodecatrien-1-ol, 3,7,11-trimethyl-, acetate, (E,E)- & 1.57 \\
30 & 1,2-Benzisothiazol-3(2H)-one & 1.61 \\
31 & Chola-5,22-dien-3-ol, (3ß,22Z)- & 1.24 \\
32 & Ephedrine & 10.87 \\
33 & Ethofumesate & 0.83 \\
34 & Trilostane & 2.79 \\
35 & Dodecanoic acid & 1.00 \\
\hline
\end{tabular}

The first five compounds were eucalyptol benzofuran, 2,3-dihydro-, trans-2-(1Pentenyl)furan, camphene, and linalool. Eucalyptol, camphene and linalool are all used as flavourings, insect repellants and for fragrances (Harborne and Baxter, 2001; Yang et al., 2004) while benzofuran, 2,3-dihydro-, trans-2-(1-Pentenyl)furan are not yet associated with any biological effects. Similarly, butanal ethylhydrazone, 2 -acetamido-d-mannitol hexanethioic acid s-ethyl ester, dotriacontane, hexatriacontane, 3,8-nonadien-2-one, (e)-, and pentalene octahydro-1-(2-octyldecyl)- have no recorded biological effects yet. Pentadecanoic acid, the 13th isolated compound is an odd chain fatty acid whereas 1,14Tetradecanediol, and 3,7,11,15-Tetramethyl-2-hexadecen-1-ol the 14th and 15th compounds have no reported biological properties. Copaene and phytol are potent antioxidants (Türkez et al., 2014; Costa et al., 2016) which provides enough scientific evidence for encouraging the application of $C$. lepidota leaves for antioxidant activities. Hexadecanoic acid (palmitic), and octadecanoic acid (stearic) were the 18th and 19th isolated components thus showing the applicability of the oil from this leaf for producing industrial products like soaps.

Palmitaldehyde, diallyl acetal, and octadecanoic acid, 2-hydroxy-1(hydroxymethyl) ethyl ester occurred in very low amounts, and have no reported biological usefulness. Myrcene (being the most abundant compound found in C. lepidota leaves), with germacrene and squalene are terpenes that posses notable immunologic effects (Mesa and Fernández, 2004; Uyeda et al., 2016).

Hence, $C$. lepidota leaves could be effective for immunotherapy. The presence of cardanol and ethofumesate might indicate slight insecticidal properties of C. lepidota leaves (Ping et al., 2005; Mukhopadhyaya et al., 2010), while 2,6,10-Dodecatrien-1-ol, 3,7,11-trimethyl-, acetate, (E,E)-, 1,2-Benzisothiazol-3(2H)-one, and Chola-5,22-dien-3-ol, $(3 \beta, 22 \mathrm{Z})$ - being the 29th-32rd isolated components, possesses no biological usefulness.

Ephedrine occurring in appreciable amount in the C. lepidota leaves imply the leaves could suffice as potent weight loss and anti-asthmatic regimen (Shekelle et al., 2003; Mei et al., 2014). Trilostane and dodecanoic acids, the 34th and 35th compounds found in C. lepidota leaves, have been found in literature to be effective in inhibiting steroidogenesis (Wenger et al., 2004) and treatment of acne (Takatsuji et al., 2009), respectively, thus broadening the pharmacological applications of $C$. lepidota leaves.

Table 2 shows the essential oil composition of I. gabonensis. Thirty two compounds were detected and quantitiated with phytol, 2-furancarboxaldehyde, 5-(hydroxymethyl)-, 1-hexadecyne, carotene, humulene, benzothiazinone, and farnesol as the main compounds. Of the first five compounds isolated; azulene, 2-furancarboxaldehyde 5-(hydroxymethyl)-, formamide n-(3-methyl-5-isoxazolyl)-, 3-pyrrolidinol, and ethanone 1-(3- 
methoxyphenyl)-, only azulene and 2-Furancarboxaldehyde, 5-(hydroxymethyl)otherwise known as hydroxymethylfurfural have potent biological effects, as antiinflammatory and antisickling agents respectively (Andersen, 1999; Abdulmalik et al., 2005).

This validates the bioprospecting of $I$. gabonensis leaves for anti-sickling effects. 1,2,3-benzenetriol, hexanoic acid, hydroxy-, methyl ester, decanoic acid, 2(1h)quinolinone, 3,4-dimethyl-, hexadecanol, and octanoic acid were the $6^{\text {th }}-11^{\text {th }}$ compound isolated respectively. Among these, only decanoic (capric), octanoic (caprylic) acids, which are food additives, and hexadecanol (cetyl alcohol), used in cosmetics, have recognized uses. Dimethyl 2,5-thiophenedicarboxylate, and hydrazinecarboxamide, 2-(2methylcyclohexylidene)-, 1,1,3-trimethyl-1-silacyclo-3-pentene, 1-hexadecyne, 9octadecyne, and 6-Octenal, 3,7-dimethyl- have no reported biological applications, while as shown in the results tetradecanoic acid, pentadecanoic, and hexadecanoic acid were found in low amounts. Further, the occurrence of humulene, farnesol, and phytol in the $I$. gabonensis leaves, among other therapeutic benefits, promotes its usage for antiinflammatory therapy (Fernandes et al., 2007; Silva et al., 2014; Chi-Mei and Jin-Yuarn,

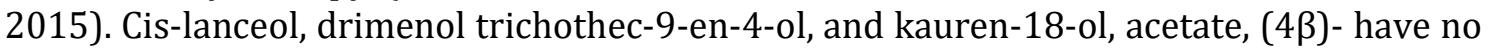
biological application yet. Carotene and benzothizone, found in moderate quantities in the I. gabonensis leaf, indicates that the extracts might be helpful for amelioration of eye problems, while the benzothiazinone content strongly suggest its usage to combat tuberculosis (Lechartier et al., 2012).

Table 2. Essential oil composition of Irvingia gabonensis leaves.

\begin{tabular}{llc}
\hline S/N & Component & Amount (\%) \\
\hline 1. & Azulene & 0.75 \\
2. & 2-Furancarboxaldehyde, 5-(hydroxymethyl)- & 17.3 \\
3. & Formamide, N-(3-methyl-5-isoxazolyl)- & 0.81 \\
4. & 3-Pyrrolidinol & 1.02 \\
5. & Ethanone, 1-(3-methoxyphenyl)- & 0.86 \\
6. & 1,2,3-Benzenetriol & 0.53 \\
7. & Hexanoic acid, hydroxy-, methyl ester & 0.67 \\
8. & Decanoic acid & 1.15 \\
9. & 2(1H)-Quinolinone, 3,4-dimethyl- & 0.7 \\
10. & Hexadecanol & 0.99 \\
11. & Octanoic Acid & 1.36 \\
12. & Dimethyl 2,5-thiophenedicarboxylate & 0.77 \\
13. & Hydrazinecarboxamide, 2-(2-methylcyclohexylidene)- \\
14. & Tetradecanoic acid & 0.83 \\
15. & 1,1,3-Trimethyl-1-silacyclo-3-pentene & 0.50 \\
16. & 1-Hexadecyne & 1.30 \\
17. & Pentadecanoic acid & 8.76 \\
18. & 9-Octadecyne & 0.64 \\
19. & Hexadecanoic acid & 1.41 \\
20. & Humulene & 2.68 \\
21. & 6-Octenal, 3,7-dimethyl- & 6.62 \\
22. & Farnesol & 0.7 \\
23. & Phytol & 3.04 \\
24. & Oleic Acid & 25.03 \\
25. & cis-Lanceol & 4.29 \\
26. & Carotene & 2.31 \\
27. & Drimenol & 7.90 \\
28. & Squalene & 0.79 \\
& & 0.70
\end{tabular}


Table 2. Continued.

\begin{tabular}{llc}
\hline S/N & Component & Amount (\%) \\
\hline 29. & Trichothec-9-en-4-ol & 0.67 \\
30. & Benzothiazinone & 4.05 \\
31. & Kauren-18-ol, acetate, $(4 \beta)-$ & 0.82 \\
\hline
\end{tabular}

The amino acids and protein qualities of both leaves were expressed in Table 3 . Both leaves recorded predominance of leucine and arginine over other essential amino acids, whereas glutamic acid and serine were the main non-essential amino acids in both leaves. Both leaves contained lower leucine contents to those of Basella alba and V. amygdalina, but showed comparable lysine values (Omoyeni et al., 2015). The isoleucine and phenylalanine contents of the leaves in this study, compared with those of popularly consumed vegetables like spinach and water leaf (Arorowa et al., 2017) but contained lower levels of tryptophan.

Valine and methionine found in this study for both leaves were high than the medicinal plants; C. esculenta and I. batatas reported by (Inyang, 2016). Arginine, histidine, of both plants, and threonine levels of I. gabonensis surpassed their respective recommended daily allowances (Ijarotimi and Olopade, 2009). Both plants similarly produced appreciable amounts of non-essential amino acids. The total amino acids for both plants were comparable whereas I. gabonensis produced slightly greater total non essential amino acids with and without histidine, total aromatic, basic, sulphur, and branched chain amino acids, while the amount of acidic amino acids were greater in C. lepidota. Only $I$. gabonensis produced aromatic amino acids equivalent to the recommended levels for infants (Amadi et al., 2017). Further, the protein quality indices showed the range of P-PERs as 1.03-2.02 for I. gabonensis, and 0.81-1.66 for C. lepidota. Both values were equivalent to those reported for millet and cowpea (Amadi et al., 2017) while the EAAI values of both leaves compared with soy (Nielson, 2002) and peanut (Adeyeye, 2010) seeds, thus implying that both leaves are suitable protein sources for diet formulations.

Table 3. Amino acid contents and protein qualities of Cola lepidota and I. gabonensis leaves.

\begin{tabular}{lcc}
\hline Amino acid & $\begin{array}{c}\text { C. lepidota } \\
\text { (g/100 g) }\end{array}$ & $\begin{array}{c}\text { I. gabonensis } \\
\text { (g/100 g) }\end{array}$ \\
\hline Essential amino acid & & \\
Leucine & $5.59 \pm 0.14$ & $6.29 \pm 0.14$ \\
Lysine & $3.46 \pm 0.04$ & $4.54 \pm 0.06$ \\
Isoleucine & $3.24 \pm 0.07$ & $3.92 \pm 0.06$ \\
Phenylalanine & $3.20 \pm 0.02$ & $3.52 \pm 0.10$ \\
Tryptophan & $0.76 \pm 0.02$ & $0.64 \pm 0.01$ \\
Valine & $3.40 \pm 0.03$ & $4.07 \pm 0.07$ \\
Methionine & $1.36 \pm 0.04$ & $1.12 \pm 0.06$ \\
Arginine & $5.76 \pm 0.06$ & $6.18 \pm 0.11$ \\
Histidine & $2.61 \pm 0.07$ & $1.58 \pm 0.09$ \\
Threonine & $1.43 \pm 0.02$ & $3.30 \pm 0.09$ \\
\hline
\end{tabular}


Table 3. Continued.

\begin{tabular}{lcc}
\hline Amino acid & $\begin{array}{c}\text { C. lepidota } \\
\mathbf{( g / 1 0 0 ~ g )}\end{array}$ & $\begin{array}{c}\text { I. gabonensis } \\
\mathbf{( g / 1 0 0 ~} \mathbf{~})\end{array}$ \\
\hline Non-essential amino acids & & \\
Proline & $2.88 \pm 0.09$ & $3.41 \pm 0.05$ \\
Tyrosine & $2.78 \pm 0.07$ & $3.05 \pm 0.05$ \\
Cystine & $0.85 \pm 0.07$ & $1.24 \pm 0.04$ \\
Alanine & $4.11 \pm 0.02$ & $3.71 \pm 0.11$ \\
Glutamic acid & $12.83 \pm 0.03$ & $9.71 \pm 0.14$ \\
Glycine & $3.36 \pm 0.05$ & $2.90 \pm 0.08$ \\
Serine & $3.12 \pm 0.05$ & $3.18 \pm 0.16$ \\
Aspartic acid & $10.18 \pm 0.20$ & $7.17 \pm 0.15$ \\
Amino acid groups & & \\
Total amino acid (TAA) & 70.92 & 69.53 \\
Total non-essential amino acid (TNEAA) & 45.87 & 40.55 \\
Total essential amino acid (TEAA) with His & 25.05 & 28.98 \\
Total essential amino acid (TEAA) without His & 23.62 & 27.40 \\
Total aromatic amino acid (TArAA) & 6.74 & 7.21 \\
Total basic amino acid (TBAA) & 10.65 & 12.30 \\
Total acidic amino acid (TAAA) & 23.01 & 16.88 \\
Total sulphur amino acid (TSAA) & 2.21 & 2.36 \\
Total branched chain amino acid (TBCAA) & 12.28 & 14.28 \\
Protein quality indices & & \\
Predicted protein efficiency ratios (P-PERs) I & 1.66 & 2.02 \\
Predicted protein efficiency ratios (P-PERs) II & 1.78 & 2.06 \\
Predicted protein efficiency ratios (P-PERs) III & 0.81 & 1.03 \\
Essential amino acid index (EAAI) & 1.33 & 1.40 \\
\hline
\end{tabular}

The fatty acid compositions of leaves of C. lepidota and I. gabonensis were presented in Table 4. C. lepidota contained a greater proportion of unsaturated fatty acids, with predominance of linolenic and linoleic acids, while I. gabonensis produced $74.46 \%$ of saturated fatty acids, having myristic, lauric, and palmitic acid as the main compounds. The result further indicated that both leaves are not richly supplied with short and very long chain fatty acids. For the unsaturated fatty acids, the linoleic acid contents of both plants were similar to those of broccoli, red cabbage and radish, whereas the linolenic acid contents of $C$. lepidota leaves in this study were higher than those reported for artichoke, asparagus, green pepper and egg plant and that of I. gabonensis compared with those for chicken pea and carrots (Virdih et al., 2009). Both leaves in this study were similar to wheat germ and olive oil, in terms of their palmitic acid contents, while out of the edible oils (Orsavova et al., 2015) like groundnut oil, sesame oil, rapeseed oil and almond oils, only coconut oil contained higher lauric acids than I. gabonensis leaves, but had lower myristic acid level. With higher unsaturated fatty acids, the consumption of $C$. lepidota leaves could improve heart health whereas the higher percentage of unsaturated fatty acids in I. gabonensis would require supplementation with richer sources of unsaturated fatty acids. 
Table 4. Fatty acid composition (\%) of C. lepidota and I. gabonensis leaves.

\begin{tabular}{lccc}
\hline Fatty acids & Formula & C. lepidota & I. gabonensis \\
\hline Caprylic acid & $\mathrm{C}_{8: 0}$ & 0.11 & 1.82 \\
Capric acid & $\mathrm{C}_{10: 0}$ & 0.53 & 2.00 \\
Lauric acid & $\mathrm{C}_{12: 0}$ & 1.07 & 21.62 \\
Myristic acid & $\mathrm{C}_{14: 0}$ & 5.63 & 25.11 \\
Myristoleic acid & $\mathrm{C}_{14: 1}$ & 0.15 & $\mathrm{ND}$ \\
Palmitic & $\mathrm{C}_{16: 0}$ & 28.01 & 16.07 \\
Palmitoleic & $\mathrm{C}_{16: 1}$ & 1.60 & 2.11 \\
Stearic acid & $\mathrm{C}_{18: 0}$ & 6.44 & 5.41 \\
Oleic & $\mathrm{C}_{18: 1}$ & 4.21 & 2.95 \\
Linoleic & $\mathrm{C}_{18: 2}$ & 14.96 & 16.77 \\
Linolenic & $\mathrm{C}_{18: 3}$ & 33.94 & 3.50 \\
Arachidic & $\mathrm{C}_{20: 0}$ & 1.85 & 1.61 \\
Eicosenoic & $\mathrm{C}_{20: 1}$ & 0.41 & $\mathrm{ND}$ \\
Eicosadienoic & $\mathrm{C}_{20: 2}$ & 0.14 & $\mathrm{ND}$ \\
Dihomo-gamma-linolenic & $\mathrm{C}_{20: 3}$ & 0.05 & $\mathrm{ND}$ \\
Behenic & $\mathrm{C}_{22: 0}$ & $\mathrm{ND}$ & 0.72 \\
Erucic & $\mathrm{C}_{22: 1}$ & $\mathrm{ND}$ & 0.13 \\
Docosadienoic acid & $\mathrm{C}_{22: 2}$ & 0.26 & $\mathrm{ND}$ \\
Lignoceric acid & $\mathrm{C}_{24: 0}$ & 0.24 & 0.08 \\
$\sum$ SFA & & 43.88 & 74.46 \\
$\sum$ EFA & & 55.72 & 25.46 \\
\hline
\end{tabular}

Results were mean \pm S.D of duplicate determination.

Figure 1 to 5 contains the free radical scavenging properties of $C$. lepidota and $I$. gabonensis leaves. All the radical scavenging potentials of both leaves illustrated in this study were concentration dependent.

The DPPH and hydrogen peroxide radical scavenging potentials of both leaves, presented in Figure 1 and 2, respectively, showed that both leaves produced higher antioxidant effects than those for standard ascorbic acid.

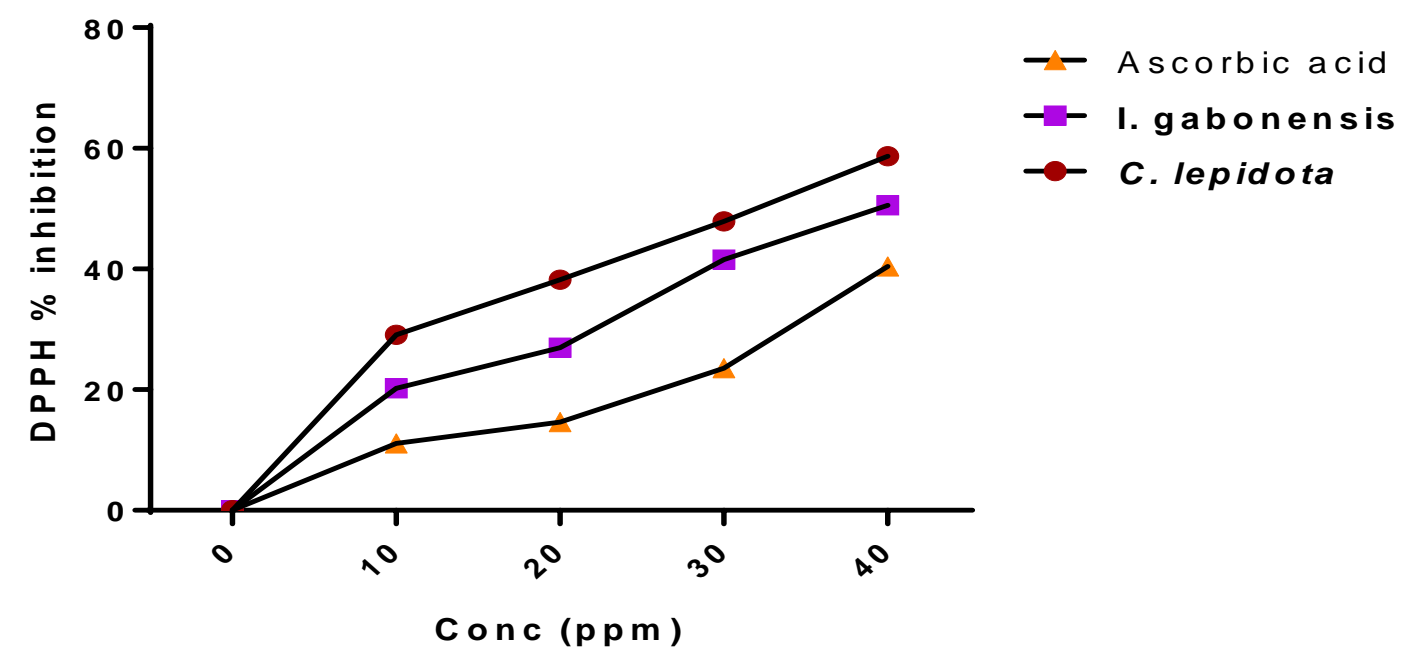

Figure 1. DPPH radical scavenging potentials of $C$. lepidota and I. gabonensis leaves. 


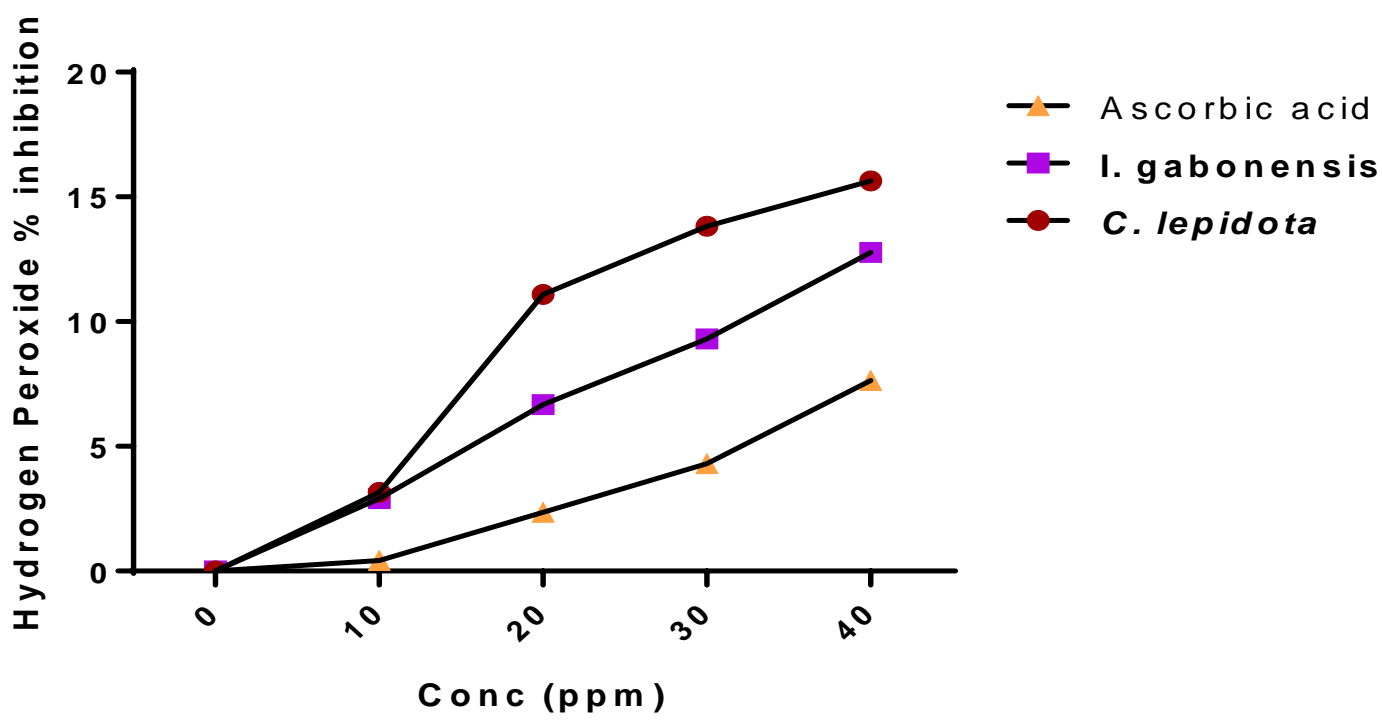

Figure 2. Hydrogen peroxide radical scavenging potentials of C. lepidota and I. gabonensis leaves.

Both leaves produced similar potentials to scavenge nitric oxide and ABTS radical scavenging potentials (Figure 3). The nitric oxide radical scavenging potentials of both leaves were similar to the standard at 30 and $40 \mathrm{ppm}$ and at $10 \mathrm{ppm}$ for ABTS. At $10 \mathrm{ppm}$, I. gabonensis produced lower FRAP than the standard trolox, but produced comparable effects with $C$. lepidota and trolox at $20 \mathrm{ppm}$, and higher effects than the trolox at 30 and $40 \mathrm{ppm}$. The high DPPH and ABTS radical scavenging effects of both leaves imply both leaves are richly supplied with phytoconstituents with hydrogen donating capacities, whereas their rich phenolic acids compositions were implicated by their potent nitric oxide scavenging (Kedare and Singh, 2011; Aluko et al., 2013). Hence, both leaves are dependable sources for the relief of oxidative stress in the system.

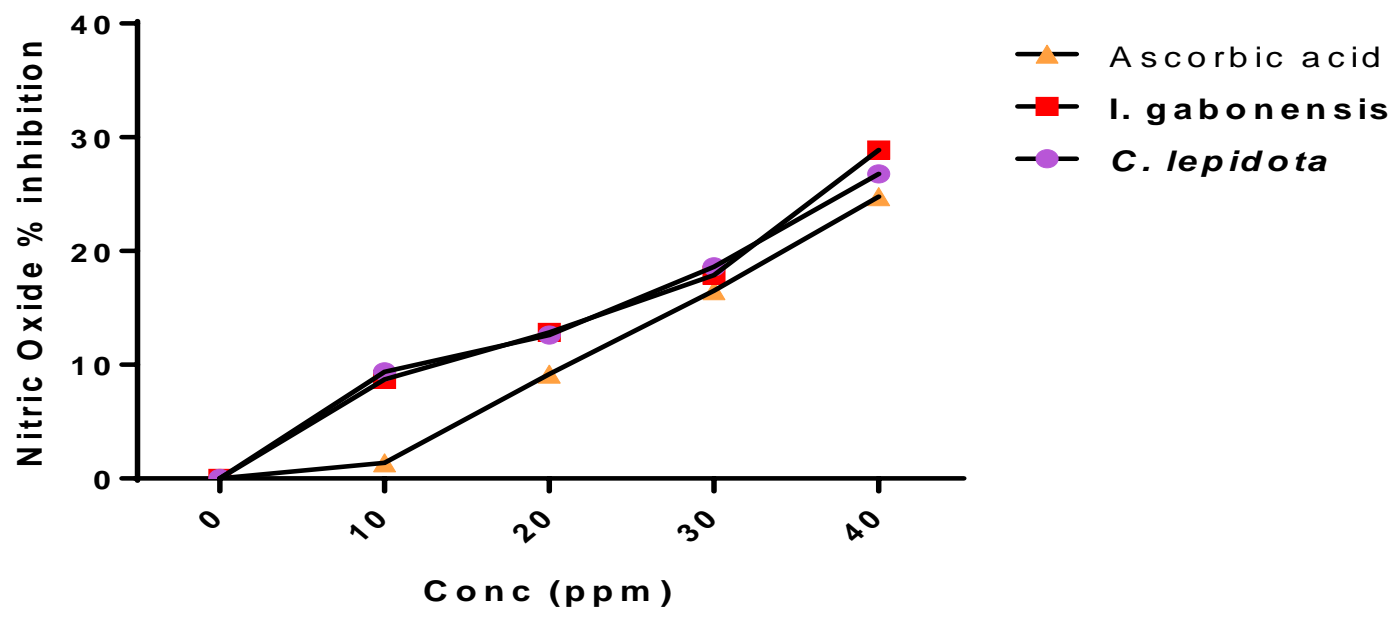

Figure 3. Nitric oxide radical scavenging potentials of $C$. lepidota and I. gabonensis leaves. 


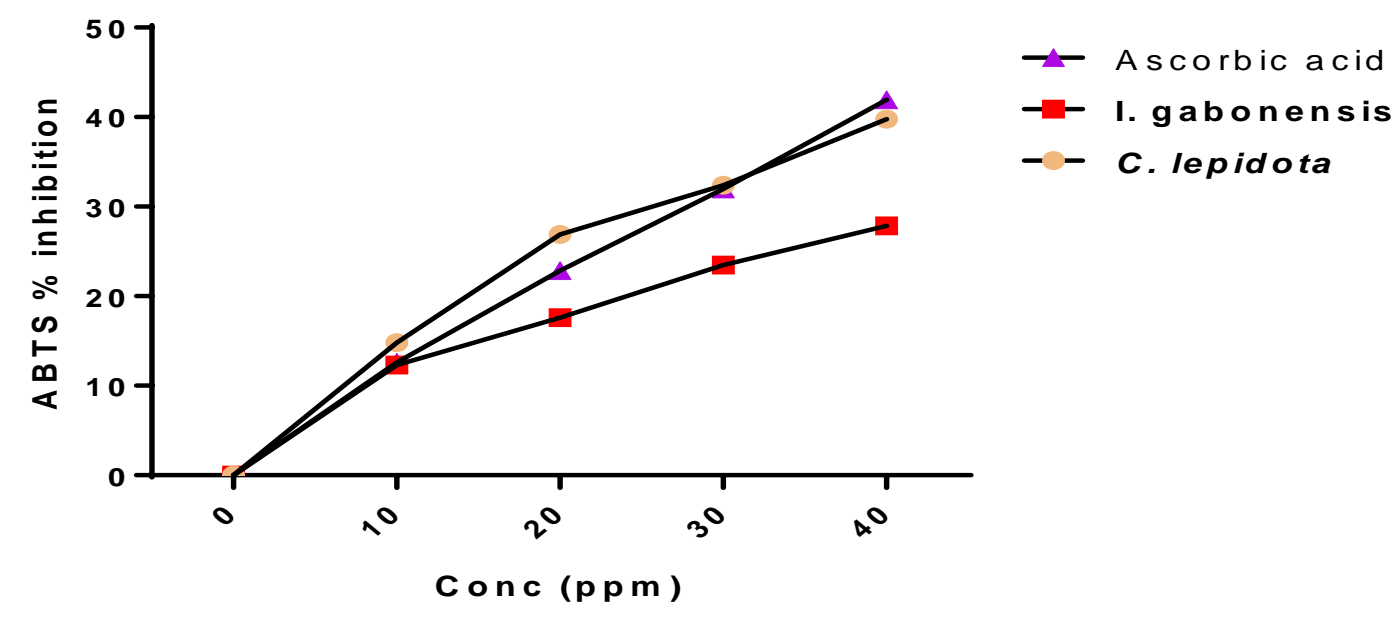

Figure 4. ABTS radical scavenging potentials of C. lepidota and I. gabonensis leaves.

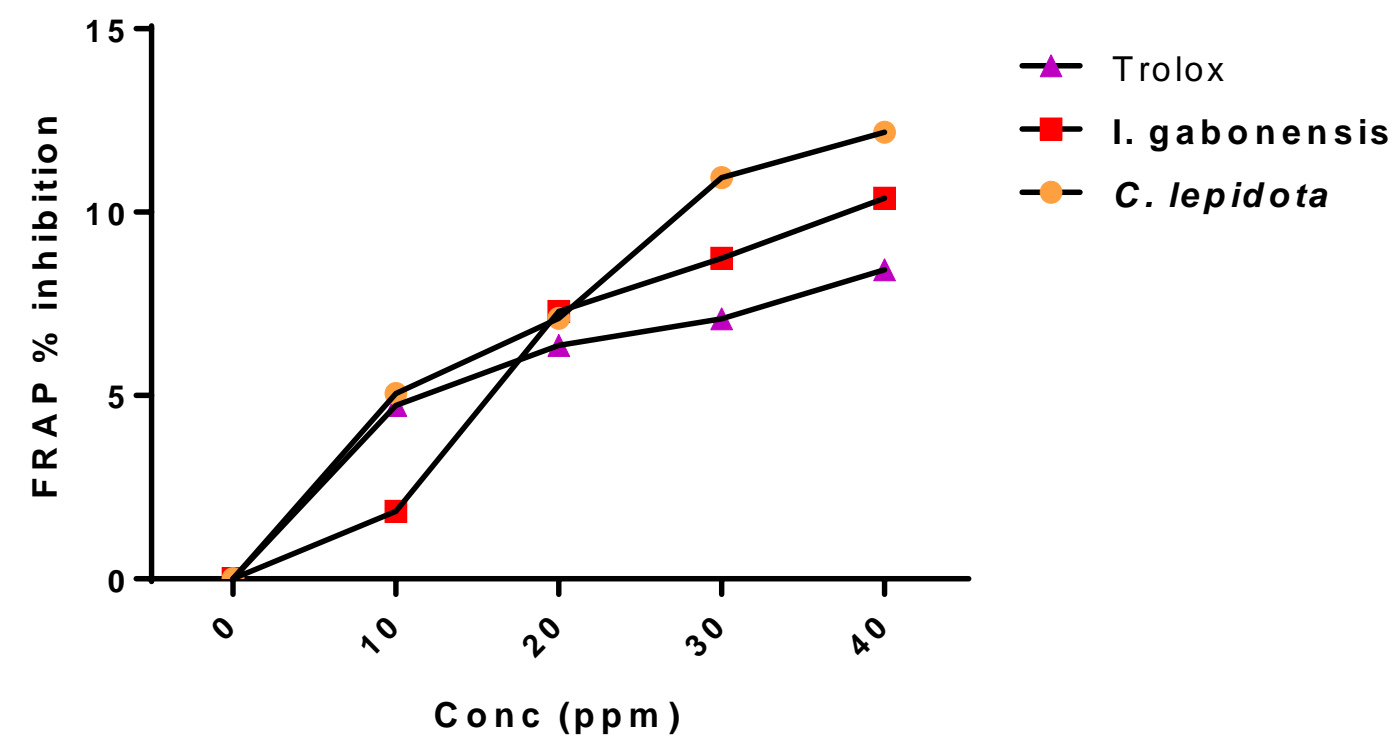

Figure 5. Ferric reducing antioxidant potentials of C. lepidota and I. gabonensis leaves.

\section{Conclusion}

This study has shown that the leaf of $C$. lepidota is richly supplied with components with potent antioxidant and immune boosting potentials whereas I. gabonensis leaves were found to contain high quantities of anti-inflammatory and anti-sickling agents. Also both leaves produced high amounts of essential amino acids, and unsaturated fatty acids on par with popularly consumed vegetables as well as demonstrated strong free radical scavenging potentials which in most of the assays were greater than standard antioxidants.

\section{Acknowledgements}

We appreciate the efforts of Prof. E.N. Agomuo for his timely contributions. 


\section{Conflicts of interest}

Authors declare that they have no conflict of interests.

\section{References}

Abdulmalik, O.; Safo, M. K.; Chen, Q.; Yang, J.; Brugnara, C.; Ohene-Frempong, K.; Abraham, D. J.; Asakura, T. 5-hydroxymethyl-2-furfural modifies intracellular sickle haemoglobin and inhibits sickling of red blood cells. British Journal of Haematology, v. 128, no. 4, p. 55261, 2005. https://doi.org/10.1111/j.1365-2141.2004.05332.x

Adeyeye, E. I. Effect of cooking and roasting on the amino acid composition of raw groundnut (Arachis hypogaea) seeds. Acta Scientarum Polonorum Technologia Alimentaria, v. 9, no. 2, p. 201-216, 2010.

Agomuo, E. N.; Amadi, P. U.; Iheka, C. U.; Duru, M. K. Impact of different processing methods on the micronutrient properties of selected legumes consumed in Eastern Nigeria. International Journal of Biological Research, v. 5, no. 1, p. 10-14, 2017. https://doi.org/10.14419/ijbr.v5i1.6711

Alam, N. N.; Jahan, B.; Rafiquzzaman, M. Review on in vivo and in vitro methods evaluation of antioxidant activity. Saudi Pharmaceutical Journal, v. 21, no. 2, p 143-152, 2013. https://doi.org/10.1016/j.jsps.2012.05.002

Aluko, B. T.; Oloyede, O. I.; Afolayan, A. J. Polyphenolic contents and free radical scavenging potential of extracts from leaves of Ocimum americanum L. Pakistan Journal of Biological Sciences, v. 16, p. 22-30, 2013. https://10.3923/pjbs.2013.22.30

Amadi, B. A.; Njoku, U. C.; Agumuo, E. N.; Amadi, P. U.; Ezendiokwere, O. E.; Nwauche, K. T. Assessment of vitamins, protein quality and mineral bioavailability of matured stems of Opuntia dillenii grown in Nigeria. Bioengineering and Bioscience, v. 5, no. 3, p. 47-54, 2017.

Andersen, F. A. Final report on the safety assessment of azulene. International Journal of Toxicology, v. 18, no. 3, p. 27-32, 1999. https://doi.org/10.1177/109158189901800304

Benitez, L. V. Amino acid and fatty acid profiles in aquaculture nutrition studies. In: Silva, S. S. (Ed). Fish nutrition research in Asia: Proceedings of the third Asian Fish Nutrition Network Meeting, 1989. p. 23-35.

Chavan, U. D.; Mckenzie, D. B.; Shahidi, F. Functional properties of protein isolates from beach pea (Lathyrus maritius L). Food Chemistry, v, 74, p. 177-187, 2001.

Chi-Mei, K.; Jin-Yuarn, L. Farnesol, a sesquiterpene alcohol in herbal plants, exerts antiinflammatory and antiallergic effects on ovalbumin-sensitized and -challenged asthmatic mice. Evidence-Based Complementary and Alternative Medicine, v. 2015, Article ID 387357, 12 pages, 2015. https://doi:10.1155/2015/387357

Costa, J. P.; Islam, M. T.; Santos, P. S.; Ferreira, P. B.; Oliveira, G. L.; Alencar, M. V.; Paz, M. F.; Ferreira, E. L.; Feitosa, C. M.; Citó, A. M.; Sousa, D. P.; Melo-Cavalcante, A. A. Evaluation of antioxidant activity of phytol using non- and pre-clinical models. Current $\begin{array}{lllll}\text { Pharmaceutical } & \text { Biotechnology, } & \text { v. 17, } & \text { no. 14, }\end{array}$ https://doi.org/10.2174/1389201017666161019155715

Ezeasor, C. K.; Chukwuma, C.; Ekere, S. O.; Abah, P. Subchronic toxicity studies of aqueous leaf and stem bark extract of Irvingia gabonensis in male albino Wistar rats. Comparative Clinical Pathology, v. 26, p. 553-559, 2017. https://doi.org/10.1007/s00580-017-2417-3 
Fernandes, E. S.; Passos, G. F.; Medeiros, R.; Cunha, F. M.; Ferreira, J.; Campos, M. M.; Pianowski, L. F.; Calixto, J. B. Anti-inflammatory effects of compounds alpha-humulene and (-)-trans-caryophyllene isolated from the essential oil of Cordia verbenacea. European Journal of Pharmacology, v. 569, no. 3, p. 228-236, 2007. https://doi.org/10.1016/ j.ejphar.2007.04.059

Grivetti, L. E.; Ogle, B. M. Value of traditional foods in meeting macro- and micronutrient needs: the wild plant connection. Nutrition Research Review, v. 13, no. 1, p. 31-46, 2000. https://doi.org/10.1079/095442200108728990

Harborne, J. B.; Baxter, H. (Ed.). Chemical dictionary of economic plants. New York: Wiley, 2001.

Ijarotimi, O. S.; Olopade, A. J. Determination of amino acid content and protein quality of complementary food produced from locally available food materials in Ondo State, Nigeria. Malaysian Journal of Nutrition, v. 15, no. 1, p. 87-95, 2009.

Lechartier, B.; Hartkoorn, R. C.; Cole, S. T. In vitro combination studies of benzothiazinone lead compound BTZ043 against Mycobacterium tuberculosis. Antimicrobial Agents and Chemotherapy, v. 56, no. 11, p. 5790-5793, 2012. https://doi.org/10.1128/AAC.0147612

Inyang, U. E. Nutrient content of four lesser: Known green leafy vegetables consumed by Efik and Ibibio People in Nigeria. Nigerian Journal of Basic and Applied Science, v. 24, no. 1, p. 1-5, 2016.

Joshi, A. R.; Joshi, K. Piscicidal plants of Bagmati watershed, Nepal: Indigenous practices. Ethnobotany, v. 17, p. 184-186, 2005.

Kedare, S. B.; Singh, R. P. Genesis and development of DPPH method of antioxidant assay. Journal of Food Science and Technology, v. 48, no. 4, p.412-422, 2011. https://doi.org/10.1007/s13197-011-0251-1

Lowe, A. J.; Gillies, A. C. M.; Wilson, J.; Dawson, I. K. Conservation genetics of bush mango from Central/West Africa: Implications for RAPD analysis. Molecular Ecology, v. 9, no. 7, p. 831-841, 2000. https://doi.org/10.1046/j.1365-294x.2000.00936.x

Mei, F.; Xing, X.-F.; Tang, Q.-F.; Chen, F.-L.; Guo, Y.; Song, S.; Tan, X.-M.; Luo, J.-B. Antipyretic and anti-asthmatic activities of traditional Chinese herb-pairs, Ephedra and Gypsum. Chinese Journal of Integrative Medicine, v. 22, no. 6, p. 445-450, 2016. https://doi.org/10.1007/s11655-014-1952-x

Mesa, C.; Fernández, L. E. Challenges facing adjuvants for cancer immunotherapy. Immunology \& Cell Biology, v. 82, p. 644-650, 2004. https://doi.org/10.1111/j.08189641.2004.01279.x

Mukhopadhyaya, A. K.; Hatib, A. K.; Tamizharasua, W.; Satya, B. P. Larvicidal properties of cashew nut shell liquid (Anacardium occidentale L.) on immature stages of two mosquito species. Journal of Vector Borne Diseases, v. 47, no. 4, p. 257-260, 2010.

Ngondi, J. L.; Etoundi, B. C.; Nyangono, C. B.; Mbofung, C. M.; Oben, J. E. IGOB131, a novel seed extract of the west African plant Irvingia gabonensis, significantly reduces body weight and improves metabolic parameters in overweight humans in a randomized doubleblind placebo controlled investigation. Lipids in Health and Disease, v. 2, no. 8, Article 7, 2009. https://doi.org/10.1186/1476-511X-8-7

Nielson, S. S. Introduction to the chemical analysis of foods. New Delhi: CBS Publishers and Distributors, 2002. 
Omoyeni, O. A.; Olaofe, O.; Akinyeye, R. O. Amino acid composition of ten commonly eaten indigenous leafy vegetables of South-West Nigeria. World Journal of Nutrition and Health, v. 3, no. 1, p. 16-21, 2015. https://doi.org/10.12691/jnh-3-1-3

Orsavova, J.; Misurcova, L.; Ambrozova, J. V.; Vicha, R.; Mlcek, J. Fatty acids composition of vegetable oils and its contribution to dietary energy intake and dependence of cardiovascular mortality on dietary intake of fatty acids. International Journal of $\begin{array}{lllll}\text { Molecular Sciences, } & \text { v. 16, no. 6, } & \text { p. 12871-12890, }\end{array}$ https://doi.org/10.3390/ijms160612871

Pamplona-Roger, G. D. Encyclopedia of foods and their healing power. Madrid: Education and Health Library, 2008.

Pellegrini, N.; Serafini, M.; Colombi, B.; Del Rio, D.; Salvatore, S.; Bianchi, M. Total antioxidant capacity of plant foods, beverages and oils consumed in Italy assessed by three different in vitro assays. The Journal of Nutrition, v. 133, p. 2812-2819, 2003. https://doi.org/10.1093/jn/133.9.2812

Ping, W.; Shu, R. J.; Jing, Q.; Qiu, X. W.; Peng, W.; Zhi, Q. Z. Stereoselective degradation of ethofumesate in turfgrass and soil. Pesticide Biochemistry and Physiology, v. 82, no. 3, p. 197-204, 2005. https://doi.org/10.1016/j.pestbp.2005.02.007

Rama Rao, M. V.; Tara, M. R.; Krishnan, C. K. Colour imetric estimation of tryptophan content of pulses. Journal of Food Science and Technology, v. 11, p. 13-216, 1974.

Rosen, E. D.; Spiegelman, B. M. Molecular regulation of adipogenesis. Annual Review of Cell and Developmental Biology, v. 16, p. 145-171, 2000. https://doi.org/10.1146/ annurev.cellbio.16.1.145

Ruch, R. J.; Cheng, S. J.; Klaunig, J. E. Prevention of cytotoxicity and inhibition of intracellular communication by antioxidant catechins isolated from Chinese green tea. Carcinogenesis, v. 10, p. 1003-1008, 1989. https://doi.org/10.1093/carcin/10.6.1003

Shekelle, P. G.; Hardy, M. L.; Morton, S. C.; Maglione, M.; Mojica, W. A.; Suttorp, M. J.; Rhodes, S. L.; Jungvig, L.; Gagné, J. Efficacy and safety of ephedra and ephedrine for weight loss and athletic performance: A meta-analysis. JAMA, v. 289, no. 12, p.1537-1545, 2003. https://doi.org/10.1001/jama.289.12.1537

Shimada, K.; Fujikawa, K.; Yahara, K.; Nakamura, T. Antioxidative properties of xanthan on the autoxidation of soybean oil in cyclodextrin emulsion. Journal of Agricultural and Food Chemistry, v. 40, p. 945-948, 1992. https://doi.org/10.1021/jf00018a005

Silva, R. O.; Sousa, F. B.; Damasceno, S. R.; Carvalho, N. S.; Silva, V. G.; Oliveira, F. R.; Sousa, D. P.; Aragão, K. S.; Barbosa, A. L.; Freitas, R. M.; Medeiros, J. V. Phytol, a diterpene alcohol, inhibits the inflammatory response by reducing cytokine production and oxidative stress.

Fundamental \& Clinical Pharmacology, v. 28, no. 4, p.455-464, 2014. https://doi.org/10.1111/fcp.12049

Singh, B.; Gupta, V.; Bansal, P.; Singh, R.; Kumer, D. Pharmacological potential of plant used as aphrodisiacs. International Journal of Pharmaceutical Sciences Review and Research, v. 5, no. 1, p. 104-113, 2010.

Steinke, F. H.; Prescher, E. E.; Hopkins, D. T. Nutritional evaluation (PER) of isolated soybean protein and combinations of food proteins. Journal of Food Science, v. 45, p. 323-327, 1980. https://doi.org/10.1111/j.1365-2621.1980.tb02606.x 
Sutharsingh, D. C. R.; Kavimani, S.; Jayakar, B.; Uvarani, M.; Thangathirupathi, A. Quantitative phytochemical estimation and antioxidant studies on aerial parts of Naravelia zeylanica. International Journal of Pharmaceutical Studies and Research, v. 2, no. 2, p. 52-56, 2011.

Takatsuji, T.; Kao, M. C.; Fang, J. Y.; Zouboulis, C. C.; Zhang, L.; Gallo, R. L.; Huang, C. M. Antimicrobial property of lauric acid against Propionibacterium acnes: Its therapeutic potential for inflammatory Acne vulgaris. The Journal of Investigative Dermatology, v. 129, no. 10, p. 2480-2488, 2009. https://doi.org/10.1038/jid.2009.93

Türkez, H.; Celik, K.; Toğar, B. Effects of copaene, a tricyclic sesquiterpene, on human lymphocytes cells in vitro. Cytotechnology, v. 66, no. 4, p.597-603, 2014. https://doi.org/10.1007/s10616-013-9611-1

Uyeda, S.; Sharmin, T.; Satho, T.; Irie, K.; Watanabe, M.; Hosokawa, M.; Hiramatsu, Y.; Koga, T.; Nakashima, Y.; Kashige, N.; Toda, A.; Mishima, K.; Miake, F. Enhancement and regulation effect of myrcene on antibody response in immunization with ovalbumin and Ag85B in mice. Asian Pacific Journal of Allergy and Immunology, v. 34, no. 4, p. 314-323, 2016.

Vidrih, R.; Filip, S.; Hribar, J. Content of higher fatty acids in green vegetables. Czech Journal of Food Sciences, v. 27, special issue, p. S125-S129, 2009.

Wenger, M.; Sieber-Ruckstuh, N. S.; Müller, C.; Reusch, C. E. Effect of trilostane on serum concentrations of aldosterone, cortisol, and potassium in dogs with pituitary-dependent hyperadrenocorticism. American Journal of Veterinary Research, v. 65, no. 9, p. 12451250, 2004. https://doi.org/10.2460/ajvr.2004.65.1245

Yang, Z.; Bengtsson, M.; Witzgall, P. Host plant volatiles synergize response to sex pheromone in codling moth, Cydia pomonella. Journal of Chemical Ecology, v. 30, no. 3, p. 619-629, 2004. https://doi.org/10.1023/b:joec.0000018633.94002.af

License information: This is an open-access article distributed under the terms of the Creative Commons Attribution License, which permits unrestricted use, distribution, and reproduction in any medium, provided the original work is properly cited. 